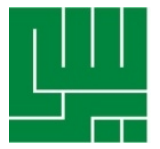

\title{
Peran School Well Being dan Keterlibatan Akademik dengan Prestasi Belajar pada Siswa Sekolah Dasar
}

\author{
Role of School Well Being and Academic Engagement on \\ Academic Performance among Elementary School Students
}

\author{
Agoes Dariyo \\ Fakultas Psikologi Universitas Tarumanagara Jakarta \\ Email: agoesd@fpsi.untar.ac.id
}

\begin{abstract}
KATA KUNCI school well being, keterlibatan akademik, prestasi akademik, siswa sekolah dasar.

KEYWORDS school well-being, academic engagement, academic performance, elementary school student.
\end{abstract}

\begin{abstract}
ABSTRAK Penelitian ini bertujuan untuk mengetahui peran school well being dan keterlibatan akademik terhadap prestasi akademik siswa. Penelitian ini melibatkan 109 siswa sekolah dasar. Pengambilan data dengan menggunakan alat ukur berupa school well being dan keterlibatan akademik. Adapun pengambilan data prestasi belajar diambil melalui hasil ulangan pelajaran matematika. Analisis data menggunakan uji korelasi dan regresi. Hasil penelitian menunjukkan bahwa ada hubungan antara school well being dengan academic engagement; tidak ada hubungan anatara school well being dengan prestasi belajar dan tidak ada hubungan antara academic engagement dengan prestasi belajar. Selain itu, ditemukan bahwa ada pengaruh school well being terhadap academic engagement.
\end{abstract}

ABSTRACT Aim of this research is to know the role of school well-being and academic engagement on the academic performance of elementary school students. There are 109 students of elementary school involve in the research. Data collecting by questionnarries such as school well-being and academic engagement. Academic performance is taken by test of math. Correlation and regression are used to analysis the data. Found, there are correlation between school well-being and academic engagement on the academic performance; , there is no correlation between school well-being and academic performance; there is no correlation between academic performance and academic performance. Beside, there is role of school well-being on the academic engagement.

PENDAHULUAN

Prestasi akademik merupakan pencapaian seorang peserta didik yang diwujudkan melalui angka, huruf atau nilai dalam sebuah lembar laporan tertulis.
Prestasi akademik sebagai hasil proses belajar selama seorang peserta didik mengikuti proses suatu pembelajaran dalam jangka waktu tertentu (Berliner and Calfee,1996; Dariyo, 2013). Prestasi 
akademik menjadi cermin konkrit dari kemampuan akademik seorang peserta didik setelah mengikuti kegiatan pembelajaran di lingkungan pendidikan formal seperti di sekolah dasar (SD), sekolah menengah pertama (SMP) atau sekolah menengah atas (SMA) atau sekolah menengah kejuruan (SMK) dan atau universitas. Karena itu, setiap lembaga pendidikan formal tersebut berupaya untuk menciptakan suasana sekolah yang menyenangkan demi merangsang setiap peserta didik dapat meraih prestasi akademik setinggitingginya (Muliani, Royanto, \& Daranti, 2009)

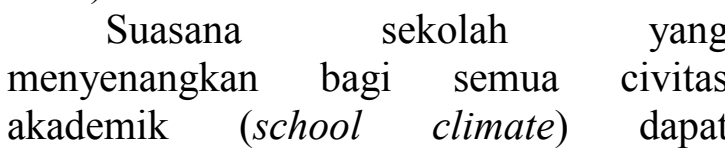
menumbuhkan semangat mengajar bagi guru dan semangat belajar bagi para peserta didik sampai kemudian menghasilkan suatu prestasi akademik (Lawhorn, 2010), dapat diistilahkan sebagai school well-being (Muliani, Royanto, \& Udaranti, 2009). School wellbeing merupakan suasana psikologis yang tercipta dalam lingkungan sekolah (Rasyidin, 2014), sehingga setiap civitas akademik merasa bahagia dalam menjalankan aktivitas di sekolah. Setiap sekolah mempunyai school well-being yang berbeda antara satu dengan yang lainnya, karena masing-masing lembaga sekolah mempunyai kebijaksanaan yang berbeda-beda. Tentu saja, perbedaan tersebut disebabkan oleh visi-misi setiap sekolah. Namun demikian, secara prinsip school well-being mengacu pada proses penciptaan suasana psikososial yang menyenangkan bagi semua individu yang terlibat dalam kegiatan pendidikan di suatu sekolah tertentu.

Bagi para peserta didik school well being dirasakan sebagai suatu kondisi yang sejahtera, menyenangkan atau membahagiakan ketika dirinya berada dalam lingkungan sekolah. Seorang peserta didik merasa nyaman untuk beraktivitas yang terkait dengan pengembangan ketrampilan akademik maupun non-akademik dalam lingkungan sekolah. Kenyamanan peserta didik menjadi hal yang penting, sebab segala hal yang ada dalam lingkungan sekolah mampu menumbuhkan dorongan bagi setiap peserta didik untuk mencapai prestasi yang terbaik (Harackiewics, Barron, Tauer, \& Elliot, 2002; Rahayu, 2011). Hal-hal yang terkait dengan lingkungan sekolah antara lain berbagai fasilitas yang mendukung kegiatan pendidikan di sekolah, munculnya perasaan memiliki bagi semua civitas akademik terhadap fasilitas dalam sekolah, dan suasana yang nyaman hubungan antar individu untuk menjalani kehidupan di sekolah. Hal ini sesuai dengan penelitian Anderman (2002) bahwa lingkungan sekolah akan memberi pengaruh terhadap kondisi psikologis bagi peserta didik. Lingkungan sekolah yang positif akan menumbuhkan perasaan tenang, nyaman dan bahkan membahagiakan bagi civitas akademik baik para peserta didik, guru atau karyawan di lingkungan sekolah tersebut.

Suasana sekolah juga akan mempengaruhi suasana yang terjadi dalam lingkungan ruang kelas (Curby, Rudasill, Edwards \& Perez-Edgar, 2011; Martin, 2011). Suasana lingkungan kelas juga harus menumbuhkan suasana yang menyenangkan bagi peserta didik untuk mengkuti kegiatan pembelajaran yang disampaikan oleh guru-gurunya (Church, Elliot, \& Gable, 2001; Do \& Schallert, 2004). Setiap peserta didik merasa senang, nyaman dan bahagia dalam mengerjakan tugas-tugas akademik (Lee, 2005) tanpa disertai dengan rasa takut, cemas atau kuatir terhadap hasil pencapaian akademiknya (Martin, 2011). Karena itu, suasana lingkungan ruang kelas akan memberi pengaruh terhadap perilaku setiap peserta didik (Boekaerts, Van Nuland \& Martens, 2010). Bila suasana lingkungan kelas bersifat positif maka setiap peserta didik akan terdorong untuk mengembangkan keterlibatan secara aktif 
dalam tugas-tugas akademik di kelas (Church, dkk 2001; Buhs, Ladd \& Herald, 2006). Sebaliknya, bila suasana kelas bersifat negatif dan tidak kondusif, maka akan mempengaruhi para peserta didik kurang aktif terlibat dalam kegiatan akademiknya (Curby dkk, 2011; Martin, 2011).

Adapun rumusan masalah yang dalam penelitian ini adalah; (1) Apakah terdapat peran school well being terhadap prestasi akademik; (2) Apakah terdapat peran school well being terhadap keterlibatan akademik; (3) Apakah terdapat peran keterlibatan akademik terhadap prestasi akademik.

\section{Prestasi Akademik}

Prestasi Akademik ialah hasil pencapaian seorang peserta didik setelah mengikuti proses belajar-mengajar dalam jangka waktu tertentu (Dariyo, 2013). Setiap peserta didik akan memperoleh hasil prestasi akademik kalau ia sudah mengikuti serangkaian proses belajarmengajar dalam jangka waktu tertentu. Prestasi akademik juga bisa disebut sebagai prestasi belajar (Santrock, 2011). Prestasi belajar diwujudkan melalui penilaian skor angka yang tercantum dalam buku raport. Biasanya buku raport akan diberikan setiap semester sekali atau 6 bulan sekali. Namun ada juga, lembaga pendidikan yang memberikan setiap triwulan atau catur wulan sekali. Hal ini tergantung dari kebijakan masing-masing lembaga pendidikan.

Prestasi akademik diberikan oleh guru atau pihak sekolah kepada setiap peserta didik. Prestasi akademik diperoleh melalui serangkaian kegiatan pembelajaran maupun berbagai ulangan, ujian atau testing yang bertujuan untuk mengetahui kemampuan seorang peserta didik dalam mengikuti proses belajar-mengajar. Seorang guru akan melakukan evaluasi pembelajaran untuk mengetahui seberapa besar atau dalam seorang murid (siswa atau peserta didik) telah memahami dan menguasai suatu materi pelajaran tertentu (mastery orientation) (Harackiewics, dkk, 2002). Seorang guru memiliki wewenang khusus untuk memberikan penilaian angka kepada setiap murid yang telah selesai mengikuti pembelajaran tertentu. Guru hanya merefleksikan taraf kemampuan akademik dari murid atau siswanya melalui penilaian skor akademik yang tercantum dalam buku raport.

\section{Keterlibatan Akademik}

Keterlibatan Akademik sebagai terjemahan dari istilah academic engagement. Keterlibatan akademik ialah kesungguhan seorang peserta didik dalam memberi perhatian selama proses pembelajaran sehingga ia merasa terdorong untuk dapat menyelesaikan tugas-tugas akademik dengan sebaikbaiknya (Martin, 2011). Dengan keterlibatan akademik, maka seorang peserta didik (siswa atau murid) menyadari akan tugas dan tanggung- jawabnya dalam mengikuti kegiatan belajar-mengajar di sekolah (Patrick, Ryan \& Kaplan, 2007). Ia merasa dirinya harus memiliki kesadaran untuk mengikuti proses pembelajaran yang diajarkan oleh gurunya (Lepper, Corpus \& Iyengar, 2005; Patrick, Ryan \& Kaplan, 2007).

Lebih lanjut Martin (2011) menyebutkan 7 dimensi keterlibatan akademik yaitu planning, task management, self-handicapping, disengagement, class participation, enjoyment of school, and positive academic intentions. Namun demikian, Martin (2011) tidak menjelaskan satu per satu dimensi tersebut. Karena itu, peneliti berupaya menjabarkan dengan pengertian sendiri. Planning ialah suatu perencanaan yang hendak dilakukan oleh peserta didik yang berkaitan dengan masalah akademik dan non-akademik di sekolah. Task management ialah suatu usaha untuk melakukan pengelolaan dalam menyelesaikan tugas-tugas akademik maupun non akademik. Self-handicapping ialah. suatu perilaku dalam pencapaian prestasi, di mana seseorang mentolerasi 
suatu kegagalan, sehingga ia memerlukan bantuan orang lain agar ia mencapai suatu keberhasilan (Corsni, 2002; VandenBos, 2007). Disengagement ialah suatu perasaan yang membuat seorang peserta didik untuk menyerah dalam menghadapi kesulitan akademik.

Class participation ialah kepedulian seorang peserta didik untuk aktif terlibat dalam kegiatan yang diatur oleh guru dalam ruang kelas (Boekaerts, Van Nuland \& Martens, 2010). Enjoyment of school ialah seorang peserta didik merasa senang untuk menikmati setiap pengalaman akativitas yang diselenggarakan oleh sekolah. Positive academic intentions ialah suatu upaya untuk melanjutkan suatu kegiatan akademik secara mandiri setelah menyelesaikan suatu kegiatan akademik di kelas atau sekolah.

Keterlibatan akademik dapat mempengaruhi keberhasilan seorang siswa dalam meraih prestasi akademik (Buhs, $\mathrm{dkk}, 2006$ ). Seorang siswa yang sungguh memiliki keterlibatan akademik, sebenarnya memiliki dorongan yang kuat untuk menguasai materi pelajaran dengan baik (Tuominen-Soini, Salmela-Aro \& Niemivirta, 2008). Ia memiliki orientasi untuk dapat memahami, mengerti dan menguasai materi pelajaran tersebut dengan sebaik-baiknya (mastery goal) (Harackiewics, Barron, Pintrich, Elliot, \& Thrash, 2002). Itulah sebabnya, siswa yang memiliki keterlibatan akademik akan mencapai prestasi akademik dengan baik pula (Furrer \& Skinner, 2003).

\section{School Well Being}

$\begin{array}{cccc}\text { School } & \text { Well } & \text { Being } & \text { ialah } \\ \text { kesejahteraan } & \text { seorang } & \text { siswa } & \text { dalam }\end{array}$ mengikuti kegiatan belajar-mengajar dalam lingkungan sekolah. Seorang siswa yang merasa sejahtera, bahagia, dan senang selama proses kegiatan belajar di sekolah, maka ia akan betah atau nyaman untuk mengikuti kegiatan belajar-mengajar yang diselenggarakan oleh sekolah tersebut. Kebahagiaan yang dirasakan oleh seorang siswa dalam bersekolah sangat dipengaruhi oleh 3 aspek yaitu having, loving dan being.

Level of Living ialah taraf seorang siswa dalam merasakan kebahagiaan dalam kehidupan selama mengikuti kegiatan belajar-mengajar di sekolah. Selama menjadi siswa, seorang individu akan terllibat dalam berbagai kegiatan akademik yang dilaksanakan oleh sekolah. Ia harus mengikuti kegiatan belajarmengajar di ruang kelas atau laboraturim yang dipandu atau diajar oleh gurunya.

Level of Having ialah bagaimana seorang siswa ikut merasakan bahwa dirinya juga merasa memiliki terhadap semua fasilitas yang disediakan oleh sekolah. Dengan ketersediaan fasilitas tersebut, maka ia akan berupaya untuk memanfaatkan beragai fasilitas tersebut untuk kemajuan studi di sekolahnya. Pihak sekolah menyediakan berbagai fasilitas demi pencapaian prestasi akademik bagi setiap siswanya. Dengan penyediaan berbagai fasilitas dalam lingkungan sekolah, maka sebenarnya pihak sekolah sedang berupaya untuk menumbuhkan perasaan memiliki (sense of belonging) dalam diri setiap civitas akademik, termasuk para siswa (Anderman, 2002).

Level of Loving (social relation) ialah bagaimana seseorang memiliki hubungan sosial dengan orang lain yaitu guru-guru, karyawan, atau kepala sekolah, atau sesama siswa di sekolah. Furrer \& Skinner (2003) menemukan social relation sangat penting bagi para siswa, karena para siswa akan meumbuhkan rasa peduli agar dapat terlibat aktif dalam kegiatan akademik. Dengan keterlibatan akademik yang baik, maka para siswa akan dapat meraih presasi akademik yang baik pula.

Menurut hasil penelitian Muliani, Royanto, dan Udaranti (2009) secara umum school well being berhubungan positif dengan keterlibatan dalam belajar siswa. Siswa yang memiliki kesejahteraan sekolah akan memiliki keterlibatan dalam bersekolah. 


\section{METODE PENELITIAN \\ Prosedur Penelitian}

Penelitian ini bersifat kuantitatif dan non eksperimen. Penelitian melibatkan siswa kelas 6 Sekolah Dasar di Jakarta Selatan. Kelas 6 terdiri dari 4 kelas dan semuanya dilibatkan dalam penelitian ini. Pengambilan data dilakukan di dalam kelas dan tidak mengganggu pelajaran sekolah, sebab dilakukan pada hari libur yaitu sabtu, bulan Oktober 2016.

\section{Kakarteristik Subjek}

Subjek penelitian adalah para siswa kelas 6 yang masih aktif terdaftar di Sekolah Dasar X, jenis kelamin laki-laki dan perempuan, tidak membedakan suku bangsa, dan status sosial ekonomi orangtuanya.

\section{Variabel-variabel dan Desain Penelitian \\ Penelitian ini melibatkan 3 variabel yaitu school well-being, keterlibatan akademik dan prestasi belajar. Desain yang dipergunakan dalam penelitian ini adalah untuk mengetahui bagaimana peran atau pengaruh variabel School Well Being terhadap keterlibatan akademik dan prestasi akademik siswa tersebut.}

\section{Alat Ukur Penelitian dan Teknik Pengumpulan Data}

Alat ukur yang digunakan untuk pengumulan data dalam penelitian adalah kuosioner. Ada dua alat ukur yaitu school well being dan keterlibatan akademik. Kedua alat ukur harus memenuhi validitas dan reliabilitas terlebih dahulu. Alat ukur school well being terdiri dari 16 butir dengan skor validitas bergerak dari 0,2 sampai dengan 0,55 ; serta reliabilitas alpha chronbach $=0,815$. Alat ukur keterlibatan akademik (academic engagement) terdiri dari 18 item dengan rentang skor validitas dari 0,274 sampai dengan 0,555, serta reliabilitas alpha chronbach $=0,829$. Adapun pengumpulan data prestasi belajar dapat diketahui melalui hasil ulangan pelajaran matematika.

\section{Teknik Analisis Data}

Teknik analisis yang digunakan dalam penelitian ini adalah korelasi Pearson, regresi linear dan dengan menggunakan program SPSS.

\section{ANALISIS DAN HASIL \\ Gambaran Data Subjek}

Jumlah subjek dalam penelitian ini sebanyak 109 orang siswa sekolah dasar. Mereka terdiri dari siswa laki-laki berjumlah 48 orang ( $44 \%$ ) dan siswa perempuan 61 orang (56\%). Umur mereka berkisar antara $11-13$ tahun. Mean $=11,7$ tahun dan $\mathrm{SD}=0,522$ ).

\section{Hasil Uji Korelasi}

Hasil uji korelasi diketahui bahwa ada hubungan antara school well being dengan academic engagement $(\mathrm{r}=0.697$, $\mathrm{p}<0,01)$; tidak ada hubungan anatara school well being dengan prestasi belajar ( $\mathrm{r}$ $=-0.088, \mathrm{p}>0,05)$; dan tidak ada hubungan antara academic engagement dengan prestasi belajar $(\mathrm{r}=0.097, \mathrm{p} \quad>$ $0,05)$.

\section{Hasil Uji Regresi}

Ada pengaruh school well being terhadap academic engagement $\left(\mathrm{r}^{2}=0.485, \mathrm{t}=10.043, \mathrm{p}<0,01\right)$. Nilai $\mathrm{r}^{2}=0.485$ artinya bahwa sumbangan school well being terhadap academic engagement sebesar 48, $5 \%$ dan ada faktor-faktor lain yang mempengaruhi academic engagement sebesar 41,5\% .

\section{Pembahasan}

Dalam pembahasan ini akan dikemukakan bagaimana hubungan antara School Well Being dan Academic Engagement, School Well Being dan Prestasi Belajar, serta Academic Engagement dan Prestasi Belajar.

School Well Being dan Academic Engagement

Hasil analisis uji korelasi membuktikan bahwa terdapat hubungan yang sangat signifikan antara school well 
being dengan academic engagement. seorang siswa yang merasakan semakin sejahtera selama belajar di sekolah, maka ia akan semakin mengembangkan kerlibatan akademik dalam pembelajaran di sekolah. Sebaliknya semakin seorang siswa merasa tidak sejahtera dalam bersekolah, maka ia tidak akan mengembangkan keterlibatan akademik di sekolahnya. Hasil penelitian tersebut mendukung temuan dari Muliani, Royanto, dan Udaranti (2009) yang mengemukakan bahwa secara umum school well being berhubungan positif dengan keterlibatan dalam belajar siswa. Siswa yang memiliki kesejahteraan sekolah akan memiliki keterlibatan dalam bersekolah.

School well being merupakan suatu perasaan bahagia yang dialami oleh seorang siswa selama mengkuti kegiatan belajar di sekolah (Anderman, 2002). Dalam penelitian ini ditemukan bahwa rerata school well being siswa laki-laki $=$ 70.1458 , rerata siswa perempuan $=$ 73.7377. Adapun nilai t (2) $=10.043$; p < 0 , 05 Jadi ada perbedaan signifikan antara laki-laki dengan perempuan. Taraf school well being siswa perempuan lebih tinggi dibandingkan dengan siswa laki-laki. Seorang siswa sadar bahwa belajar itu merupakan aktivitas yang menyenangkan, karena dengan kegiatan belajar, maka seorang siswa akan memperoleh peningkatan pengetahuan dan wawasan yang akan berguna di masa yang akan datang. Siswa menyadari betapa pentingnya untuk mengikuti kegiatan belajar di sekolah. Dengan belajar di sekolah berarti seorang siswa sedang meningkatkan kemampuan akademik (Hamachek, 1990: Slavin, 2012). Ia akan dilatih oleh para gurunya untuk memecahkan masalah-masalah akademik. Itulah sebabnya, ia harus mengembangkan dan memiliki sikap yang aktif untuk terlibat dengan sungguh-sungguh agar ia dapat menyelesaikan masalah akademiknya dengan baik.

Hasil uji regresi menunjukkan bahwa terdapat peran yang signifikan school well being terhadap academic engagement $\left(\mathrm{r}^{2}\right.$ $=0,485, \mathrm{t}=10.043, \mathrm{p}<0,01)$. Adapun nilai $\mathrm{r}^{2}=0,485$ menunjukkan bahwa sumbangan school well being terhadap academic engagemen adalah sebesar 48,5 $\%$. Jadi masih ada faktor-faktor lain sebesar 51, $5 \%$ yang mempengaruhi academic engagement. Dengan adanya kesejahteraan seorang siswa dalam menjalani akativitas belajar mengajar di sekolah, maka ia semakin sungguhsungguh untuk mengembangkan keterlibatan akademiknya di sekolah.

Academic Engagement (Keterlibatan akademik) ialah kesungguhan seorang peserta didik dalam memberi perhatian selama proses pembelajaran sehingga ia merasa terdorong untuk dapat menyelesaikan tugas-tugas akademik dengan sebaik-baiknya (Martin, 2011). Seorang siswa yang memiliki keterlibatan akademik ialah seorang siswa yang menyadari akan tugas dan tanggungjawabnya sebagai pelajar yang belajar terhadap guru-guru yang mengajar dan membimbingnya dengan baik. Dalam penelitian ini diketahui bahwa rerata siswa laki-laki $=70.521$, rerata siswa perempuan $=74.312$. Jadi ada perbedaan antara siswa laki-laki dengan siswa perempuan. Siswa perempuan lebih tinggi memiliki keterlibatan akademik dibandingkan dengan siswa laki-laki.

\section{School Well Being dan Prestasi Belajar}

Hasil uji korelasi menunjukkan bahwa tidak ada hubungan antara school well being dengan prestasi belajar. Dengan demikian, hipotesis yang diajukan dalam penelitian ini ditolak atau tidak diterima. Seorang siswa boleh saja memiliki kesejahteraan secara psikologis ketika belajar di sekolah, namun bukan berarti ia akan dapat mencapai prestasi belajar dengan hasil yang terbaik. Kesejahteraan yang dialami oleh seorang siswa bukanlah penentu baginya untuk dapat mencapai prestasi belajar dengan baik. Andaikan seorang siswa memiliki kesejahteraan selama belajar di sekolah, namun kalau ia 
tidak belajar sungguh-sungguh terhadap materi pelajaran yang diajarkan oleh gurunya, maka sia-sialah perasaaan sejahtera siswa tersebut (Thompson \& Zamboanga, 2004; Schunk at al, 2008).

Pencapaian prestasi belajar seorang siswa dipengaruhi oleh faktor-faktor seperti kecerdasan, minat-bakat, motivasi dan sebagainya (Slavin, 2012; Santrock, 2011; Rahayu, 2011; Dariyo, 2013). Jika seseorang siswa hanya mengandalkan perasaan bahagia (sejahtera) selama bersekolah, namun tanpa disertai dengan kemampuan kognitif seperti kecerdasan, minat-bakat atau aspek afektif (motivasi), maka ia tidak mungkin mencapai prestasi belajar dengan baik. Kecerdasan ialah kemampuan untuk memecahkan masalah masalah secara akademik (Santrock, 2011). Kecerdasan sangat penting untuk dapat mendukung keberhasilan seorang siswa meraih prestasi belajar. Minat dan bakat juga memberi peran terhadap pencapaian prestasi belajar seorang siswa (Boekeaerts at al, 2010). Jika seorang siswa tidak berminat dan juga tidak berbakat dalam suatu pelajaran tertentu, maka ia pun tidak akan meraih prestasi belajar dengan baik. Demikian pula, motivasi ialah dorongan yang menggerakkan seseorang untuk mencapai suatu tujuan tertentu (Gottfried dkk, 2001; Pintrich, 2003; Boekeaerts dkk 2010; Lee, 2005; Schunk, Pintrich, and Meece, 2008). Dengan motivasi, maka seorang siswa akan belajar giat, tidak mudah menyerah dan fokus mencapai tujuan sampai memperoleh keberhasilan dengan baik (Pintrich, 2003; Sardiman, dalam Rahayu, 2011). Jika seorang siswa tidak memiliki motivasi yang tinggi, maka ia pun juga tidak akan mencapai prestasi belajar dengan baik (Boekeaerts dkk, 2010; Schunk, Pintrich, \& Meece, 2008).

Hasil uji korelasi tidak menemukan hubungan antara Academic Engagement dengan Prestasi Akademik. Seorang siswa memang harus memiliki keterlibatan secara akademik (academic engagement) selama kegiatan belajar di sekolah. Ia harus bersungguh - sungguh mengembangkan sikap untuk belajar mempelajari dan menguasai materi pelajaran dengan baik. Sikap untuk menguasai materi suatu pelajaran, sehingga seorang siswa dapat menyelesaikan suatu masalah akademik dengan baik disebut mastery orientation. Seorang siswa yang benar-benar menguasai materi pelajaran dengan baik, maka ia diharapkan dapat meraih prestasi belajar yang terbaik (Santrock, 2011).

Namun demikian, hasil penelitian ini sangat jauh dari harapan teori atau hipotesis yang menyatakan bahwa keterlibatan akademik akan memberi kontribusi terhadap pencapaian prestasi belajarnya. Dengan demikian, maka hipotesis yang diajukan dalam penelitian ini tidak diterima atau ditolak. Seorang siswa yang memiliki keterlibatan akademik bukan menjadi penentu baginya untuk dapat meraih prestasi belajar di sekolah. Keterlibatan akademik (Academic Engagement) saja tidak cukup menjadi dasar untuk meraih presasi belajar bagi seorang siswa (Slavin, 2012). Bila ia terlibat scara akademik, namun bila ia tidak menguasai materi pelajaran dengan baik, maka ia tidak akan berhasil untuk menghadapi tugas-tugas dan masaahmasalah akademik di sekolah. Dengan demikian, keterlibatan akademik seharusnya mendorong seorang siswa untuk menguasai materi pelajaran dengan baik (Pintrich, 2003; Schunk, Pintrich and Meece, 2008). Lebih lanjut, Gottfried at al, (2001) dan Schunk at all (2008) menyatakan bahwa motivasi internal yang kuat akan mendorong seorang siswa untuk bersungguh-sungguh untuk menghadapi berbagai tugas akademik sampai ia meraih keberhasilan secara akademik. Itulah sebabnya, keterlibatan akademik seharusnya sebagai perwujudan dari motivasi internal yang berdampak pada prestasi belajar (Gottfried at al, 2001). Namun kenyataannya, keterlibatan akademik dalam penelitian ini tidak 
memiliki hubungan dengan prestasi belajar pada siswa.

\section{SIMPULAN}

Dapat disimpulkan bahwa ada hubungan signifikan antara School Well Being dengan Keterlibatan Akademik. Demikian pula, ada peran yang signifikan School Well Being terhadap Academic Engagement pada siswa sekolah dasar. Selain itu, ada hubungan antara School Well Being dengan Keterlibatan Akademik serta tidak ada hubungan antara Keterlibatan Akademik dan Prestasi Belajar pada siswa sekolah dasar.

\section{SARAN}

Disarankan bahwa penelitian selanjutnya dapat melibatkan variabelvariabel lain yang bertujuan untuk membuktikan hubungan atau peran yang berkontribusi terhadap prestasi belajar, antara lain; mastery orientation, minat, bakat, atau kecerdasan. Sebab keterlibatan akademik saja tidak cukup, namun jika tidak disertai penguasaan materi pelajaran (mastery orientation). Karena itu, seorang siswa yang terlibat secara akademik dan menguasai materi pelajaran dengan baik, maka ia akan mencapai prestasi belajar yang terbaik pula.

Saran-saran praktis yang dapat dilakukan oleh seorang siswa ialah siswa selayaknya mengembangkan kesejahteraan selama belajar di sekolah (school well being). Dengan school well being, seorang siswa akan merasa bahagia ketika belajar di sekolah, sehingga ia sungguh-sungguh terlibat secara akademik di sekolah.

\section{Ucapan Terimakasih}

Penulis mengucapkan rasa terimakasih yang sebesar-besarnya atas dukungan dana yang diberikan oleh Lembaga Penelitian dan Publikasi Ilmiah (LPPI) Universitas Tarumanagara Jakarta sehingga kegiatan penelitian ini dapat dilaksanakan dengan sebaik-baiknya.

\section{DAFTAR PUSTAKA}

Anderman, E. M. (2002). School effect on psychological outcomes during adolescence. Journal of Educational Psychology, 94 (4), 795-809.

Berliner, D.C \& Calfee, R. C (Eds). (1996). Handbook of educational psychology. London: Macmillan Library Reference USA and Simon \& Schuster Macmillan.

Boekaerts, M., Van Nuland, H and Martens, R. (2010). Perspective on motivation: what mechanisms energise students' behavior in the classroom. In International handbook of psychology in education. United Kingdom: Emerald.

Buhs, E, S., Ladd, G.W., and Herald, S. L. (2006). Peer exclusion and victimization: processes that mediate the relation between peer group rejection and children's classroom engagement and achievement ?. Journal of Educational Psychology, 98 (1), 1-13.

Church, M. A, Elliot, A.J \& Gable, S.L (2001). Perceptions of classroom environment, achievement goals and achievement outcomes. Journal of Educational Psychology. .93, 43-54.

Corsni, R. (2002). The Dictionary of psychology. London: Brunner / Routledge.

Curby, Rudasill, Edwards and Perez-Edgar, (2011). The Role of classroom quality in amelioating the academic and social risks associated with difficult temperament. School Psychology Quartely, 26 (2), 175-188.

Dariyo, A. (2013). Dasar-dasar pedagogi modern. Jakarta: Indeks.

Do, S. L \& Schallert, D. L. (2004). Emotion and classroom talk: Toward a model of the role of affect in student'experiment of classroom discussion. Journal of Educational Psychology, 96 (4), 619634.

Furrer, C., \& Skinner, E. (2003). Sense of relatedness as a factor in children's academic engagement and performance. Journal of Educational Psychology, 95 (1), 148-162.

Gottfried, A. E., Fleming, J. S., \& Gottfried, A. W.(2001). Continuity of academic intrinsic motivation From childhood through late adolescence: A 
longitudinal study. Journal of Educational Psychology. 93 (1), 3- 13.

Hamachek, D. (1990). Psychology in teaching, learning and growth. (4 ${ }^{\text {th }}$ edition). Boston: Allyn and Bacon.

Harackiewics, J. M, Barron, K. E, Tauer, J. M \& Elliot, J. A. (2002). Predicting success in college: A Longitudinal study of achievement goals and ability measures as predictor of interest and performance from freshman year through graduation. Journal of Educational Psychology, 94 (3). 562575.

Harackiewics, J. M, Barron, K. E, Pintrich, P. R, Elliot, A.J \& Thrash, T.M (2002). Revision on achievement goal theory: Necessary and illuminating. Journal of Educational Psychology, 94 (4), 638645.

Lawhorn, J. B. (2010). School size and Its effect on school climate and academic achievement in rural south georgia high school. Electronic Theses \& Dissertations. Jack N. Averittt College of Graduate Studies.

Lee, S. W.(2005). Encyclopedia of School Psychology. London: Sage Publication.

Lepper, M, R., Corpus, J. H., \& Iyengar, S. S. (2005). Intrinsic and extrinsic motivational orientation in the classroom: Age differences and academic correlates. Journal of Educational Psychology, 97 (2), 184196.

Martin, A. J. (2011). Courage in the classroom: exploring a new framework predicting academic performance and engagement. School Psychology Quartely, 26 (2), 145-160.

Muliani, A, Royanto, L, R, M \& Udaranti, W, S. (2009). Hubungan antara school well being dan keterlibatan dalam kegiatan belajar pada siswa SMA kelas 1.
Manasa, Jurnal Ilmiah Psikologi, 01 (01), 100-107.

Pintrich, P. R. (2003). A Motivational science perspective on the role of student motivation in learning and teaching context. Journal of Educational Psychology, 95 (4), 667-686.

Patrick, H., Ryan, A. M., \& Kaplan, A. (2007). Early adolescents's perceptions of the classroom social environment, motivational beliefs and engagement. . Journal of Educational Psychology, 99 (1), 83-98.

Rasyidin, W. (2014). Pedagogik: teoretis dan praktis. Bandung: Remaja Rosdakarya.

Rahayu, W. P. (2011). Analisis intensitas pendidikan oleh orangtua dalam kegiatan belajar anak, status sosial ekonomi orangtua terhadap motivasi belajar dan prestasi belajar siswa. Jurnal Pendidikan \& Pembelajaran, 18 (1), $72-$ 80.

Santrock, J. W. (2011). Education psychology. Boston: McGraw-Hill.

Schunk, D. H., Pintrich, P. R \& Meece, J. L. (2008). Motivation in education. $\left(3^{\text {rd }}\right.$ edition). New Jersey: Upper Saddle River.

Slavin, R. E. (2012). Educational psychology: Theory and practice. (10 ${ }^{\text {th }}$ edition). Boston: Pearson.

Thompson, R. A \& Zamboanga, B. L. (2004). Academic aptitude and prior knowledge as predictors of atudent achievement in introduction to psychology. Journal of Educational Psychology, 96 (4), 778784.

Tuominen-Soini, S \& Niemivirta, A. (2008). Achievement goal orientation and subjective bell-being: A person-centred analysis. Learning and Intruction, 18, 251-266.

VandenBos, G. R. (ed) (2007). APA dictionary of psychology. ashington, DC: American Psychological Association. 